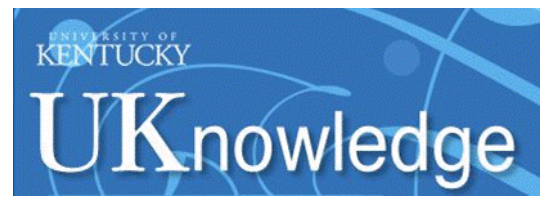

University of Kentucky

UKnowledge

Biosystems and Agricultural Engineering Faculty Publications

Biosystems and Agricultural Engineering

7-1998

\title{
Comparison of Observed and Simulated Grow-Finish Swine Performance Under Summer Conditions
}

\author{
Larry W. Turner \\ University of Kentucky \\ Thomas C. Bridges \\ Richard D. Coffey \\ Richard S. Gates \\ University of Kentucky \\ Gary R. Parker \\ University of Kentucky
}

University of Kentucky, tom.bridges2@uky.edu

University of Kentucky, rcoffey@uky.edu

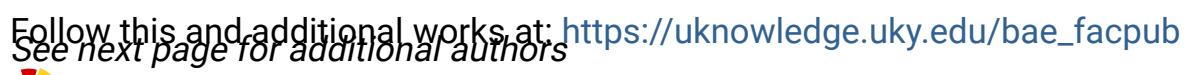

Part of the Animal Sciences Commons, Bioresource and Agricultural Engineering Commons, and the Environmental Sciences Commons

Right click to open a feedback form in a new tab to let us know how this document benefits you.

\section{Repository Citation}

Turner, Larry W.; Bridges, Thomas C.; Coffey, Richard D.; Gates, Richard S.; Parker, Gary R.; Brown-Brandl, Tami M.; and Overhults, Douglas G., "Comparison of Observed and Simulated Grow-Finish Swine Performance Under Summer Conditions" (1998). Biosystems and Agricultural Engineering Faculty Publications. 117.

https://uknowledge.uky.edu/bae_facpub/117

This Article is brought to you for free and open access by the Biosystems and Agricultural Engineering at UKnowledge. It has been accepted for inclusion in Biosystems and Agricultural Engineering Faculty Publications by an authorized administrator of UKnowledge. For more information, please contact UKnowledge@lsv.uky.edu. 
Comparison of Observed and Simulated Grow-Finish Swine Performance Under Summer Conditions

Digital Object Identifier (DOI)

https://doi.org/10.13031/2013.19397

Notes/Citation Information

Published in Applied Engineering in Agriculture, v. 14, issue 4, p. 419-423.

(c) 1998 American Society of Agricultural Engineers

The copyright holder has granted the permission for posting the article here.

Authors

Larry W. Turner, Thomas C. Bridges, Richard D. Coffey, Richard S. Gates, Gary R. Parker, Tami M. BrownBrandl, and Douglas G. Overhults 


\title{
Comparison of ObSERVEd and Simulated Grow-Finish Swine PERFormance Under SUMmer CONDITIONS
}

\author{
L. W. Turner, T. C. Bridges, R. D. Coffey, R. S. Gates, G. R. Parker, T. M. Brown-Brandl, D. G. Overhults
}

\begin{abstract}
As a part of a National Pork Producers Council educational program, our research and extension team at the University of Kentucky was linked with an independent commercial swine producer to test the NCPIG model against observed commercial on-farm data. This experience provided improved information for model development as well as increased producer insight into the data input needs and potential benefits of modeling. Detailed production information comparisons between the NCPIG model and producer data are presented for summer time conditions to assess the validity of the NCPIG model for simulation of grow-finish swine performance. Results demonstrated that the NCPIG model accurately simulated performance. Keywords. Pigs, Modeling, Simulation, Growth.
\end{abstract}

$\mathrm{T}$ he NCPIG computer model (Bridges et al., 1992a,b; Usry et al., 1992) was developed to predict feed intake and growth of growing/finishing pigs [20-110 kg (45-240 lb)] as influenced by changes in nutrition, environment and genetics. The NCPIG program was developed as a part of a regional project (NC-204) of several land-grant universities in the U.S. The regional committee was established by the Agricultural Experiment Stations of the North Central Region with its members having interests in the areas of nutrition, engineering, bio-energetics, environment, economics, breeding, physiology, and systems analysis. One major objective of this committee was to develop a physiologically based model (NCPIG) capable of predicting responses of growing swine for various feeding and environmental conditions. The physiological emphasis of the model means it is more biologically accurate than many empirical (regression-type) models, but also means it is necessarily a complex model. The model originally ran on a mainframe computer because of its complexity, and

Article was submitted for publication in October 1997; reviewed and approved for publication by the Structures \& Environment Div. of ASAE in April 1998.

The investigation reported in this article (No. 97-05-160) is in connection with a project of the Kentucky Agricultural Experiment Station and is published with the approval of the director. This article was originally prepared for the Fifth International Livestock Environment Symposium, Minneapolis, Minnesota, 29-31 May 1997.

The authors are Larry W. Turner, ASAE Member Engineer, Extension Professor, and Thomas C. Bridges, ASAE Member Engineer, Research Specialist, Department of Biosystems and Agricultural Engineering, University of Kentucky; Richard D. Coffey, Assistant Extension Professor, Department of Animal Sciences, University of Kentucky; Richard S. Gates, ASAE Member Engineer, Professor, Department of Biosystems and Agricultural Engineering, University of Kentucky; Gary R. Parker, Extension Professor, Department of Animal Sciences, University of Kentucky; and Tami M. Brown-Brandl, ASAE Member, Graduate Research Assistant, and Douglas G. Overhults, ASAE Member Engineer, Associate Extension Professor, Department of Biosystems and Agricultural Engineering, University of Kentucky, Lexington, Ky. Corresponding author: Larry W. Turner, Department of Biosystems and Agricultural Engineering, 128 Agric. Eng. Bldg., University of Kentucky, Lexington, KY 40546-0276; tel: (606) 257-3000, ext. 109; fax: (606) 257-5671; e-mail: lturner@bae.uky.edu. only recently (with the advent of 486 and Pentium class PCs) has been run on a personal computer.

The goal of the NCPIG model development effort is to provide a tool to producers, researchers, extension personnel and agribusiness personnel that will allow testing of various swine feeding, housing and management strategies using the computer rather than actual animals, and will aid understanding of the physiology of the pig. The computer offers a means of predicting live animal response through computer simulation. Additionally, with rapidly changing genetics and the advent of biotechnology, growth promotants, and new lean marketing strategies, modeling offers a means of evaluating these changes more rapidly than possible with live animal research, e.g., predicting body composition without requiring expensive carcass measurements.

For any such computer model, the program must be tested to verify that it does an acceptable job of predicting the pig's response. The NCPIG model is written in FORTRAN and can be run on an IBM compatible 486- or Pentium-class PC. The NCPIG model has been tested extensively against laboratory data (Bridges et al., 1992a,b; Usry et al., 1992). However, the comparisons described in this article are the first detailed comparisons we have made with production data from a commercial farm.

In 1995, as a part of a National Pork Producers Council educational program, our research and extension team at the University of Kentucky was linked with an independent commercial swine producer, Phillip Lyvers, to test the NCPIG model against observed commercial farm data. This experience provided improved information for model development as well as increased producer (cooperator) insight into the data input needs and potential benefits of modeling. Detailed comparisons between the NCPIG model and producer data are presented in this article to assess the validity of the NCPIG model for simulation of grow-finish swine performance during summer conditions.

\section{MOdEl BACKGROUND AND CONCEPTS}

Mechanistic (deductive) mathematical models of the growth performance of swine as influenced by nutrition, 
genetics and environment offer a means of predicting performance under a broader range of conditions as compared to empirical models. Several mechanistic models have been developed and each has certain limitations (such as a lack of either nutrition or environment components). Additionally, most include substantial empirical (regression-type) relationships between different parameters. These models include those of Teter et al. (1973), Whittemore and Fawcett (1976), and Bruce and Clark (1979). Recently, several models have been developed which include the influence of both environment and nutrition while also incorporating genetic variation and the prediction of carcass characteristics and composition. Two models, the NCCISWINE (pre-cursor to SWINEGRO) model (Watt et. al., 1987; DeShazer et al., 1988) and the NC-204 micro-model (Ewan and DeShazer, 1988), are based upon the Whittemore model with inclusion of environmental components and ad libitum feeding. Black et al. (1986) developed a model (AUSPIG) which incorporates nutrition, genetics and environment into a comprehensive deterministic model of swine intake and growth while Moughan et al. (1987), Pomar et al. (1991), and Fialho et al. (1997a,b) developed models with similar goals but initially without the environmental component. The latter three models are based on fundamental principles to a greater extent than the models mentioned previously.

None of the previously referenced models, except Fialho et al. (1997a,b), has the capability of representing diurnal variations of animal environment and the resulting variation in swine performance response. Time progression in most of the above models is based upon daily time increments or steady-state conditions and reliable responses for those models are therefore at best limited to daily values. Feed intake is modeled in most cases by empirical relationships to reflect some influences of environment on ad libitum intake. The NCPIG model (Bridges et al., 1992a,b; Usry et al., 1992) considers the interaction of nutrition, genetics, body composition and environment on a time-varying basis over the day. In the NCPIG model, fundamental principles are used as opposed to regression relationships to predict how ad libitum intake is influenced by environment, nutrition, and genetics. Further details are available regarding the NCPIG model in the listed references.

\section{The NCPIG Production Statistics}

Within the NCPIG model, a summary of production statistics is computed for each day or group of days that an output is specified. Once the empty body components of protein, fat, water, and ash have been updated, a live weight is calculated based upon the empty body tissue component weights. Once the live weight has been determined, the 'hot' carcass weight, hot dressing percentage and last rib ruler and Fat-O-Meater backfat thickness are computed, as well as standard uniform lean information such as 10th rib backfat and fat-free-leanindex (FFLI), average daily gain, and feed intake statistics.

\section{Materials AND METHODS \\ COOPERATING FARM DESCRIPTION}

The Phillip Lyvers swine operation is located near Loretto, Kentucky, and participates in a marketing network of over 35 independent swine producers. Excellent records are kept, including weight entering the grow-finish $(\mathrm{G}-\mathrm{F})$ building and feed consumption per group. During 1996, animal live weights and feed intake were measured on approximately two-week time intervals over the growfinish period.

\section{ANIMALS}

The animals on the Lyvers farm are primarily bred from Duroc terminal sires and three-way female crosses of Landrace/Duroc/Yorkshire genetics, and raised farrow to finish. For this study, two grow-finish periods were compared to results simulated by NCPIG for 1995: (a) 15 June-Sep/Oct (white group); and (b) 5 July-October (red group). In the white group, 164 gilts and 157 barrows were observed and simulated. For the red group, 122 gilts and 182 barrows were used for performance observations and model comparisons. The colors are not indicators of genetics, but are used by Mr. Lyvers in record-keeping to identify groups of pigs. Initial live weight was measured when the pigs were moved from the nursery to the growfinish facilities. Carcass data from kill sheets included means and ranges for live weight at slaughter, hot carcass weight, lean percent, back fat thickness, and fat-free lean index (FFLI). No initial carcass data were obtained for any of the pig groups. In 1996, one grow-finish period was studied: 5 June-September (green group). During the 1996 period, animal live weights were measured at approximately two week intervals over the grow-finish period in addition to the initial and slaughter weights. Weights were obtained using a pen-type scales arrangement, thus only group weights were obtained as opposed to individual animal weights.

\section{FEED}

Feed used during 1995 was a corn-soy based ration with two phases being fed for the barrows, and one feed for the grow-finish period for all gilts. During 1996, the one or two phase program was altered to feed four diets to each sex. During the summer periods of 1995, one diet was fed for barrows from 18 to $60 \mathrm{~kg}$ (40-130 lb) (Diet 1), and a second (Diet 2) for barrows from $60 \mathrm{~kg}(130 \mathrm{lb})$ market weight. Gilts were fed Diet 1 continuously through the grow-finish period. Table 1 provides a description of each diet. During the summer of 1996, four diets were fed for each sex, as indicated in table 2. For each diet, records of total weight fed in each group were collected over the grow-finish period. Feed weight for the selected pen feeders was measured using calibrated volumetric meters to record the number of times a given volume was delivered to each pen through the overhead auger system. Feed wastage was minimized by wellmanaged feeders, but no attempt was made to quantify feed wastage.

\section{FACILITIES AND ENVIRONMENT}

Hogs are split-sex fed in curtain-sided naturally ventilated buildings, with thermostatically controlled sprinkler systems. The buildings are $7.3 \mathrm{~m}(24 \mathrm{ft})$ wide $\times$ 
Table 1. Phillip Lyvers swine rations, white and red groups, 1995

\begin{tabular}{|c|c|c|}
\hline Feedstuff Ingredients & $\begin{array}{c}\text { Diet No. 1 } \\
20-60 \mathrm{~kg}(45-130 \mathrm{lb}) \text { Barrows } \\
20 \mathrm{~kg}(45 \mathrm{lb})-\mathrm{mkt} \text {. Gilts } \\
\% \text { Each Feedstuff by Weight }\end{array}$ & $\begin{array}{l}\text { Diet No. } 2 \\
60 \mathrm{~kg}(130 \mathrm{lb})-\mathrm{mkt} \text {. Barrows } \\
\% \text { Each Feedstuff by Weight }\end{array}$ \\
\hline Corn & 76.45 & 80.525 \\
\hline Soy bean meal (SBM) (48\%) & 20 & 16.25 \\
\hline $\begin{array}{l}\text { Suppl. or pre-mix: } \\
\text { Vitamin } \\
\text { Lysine } \\
\mathrm{CuSO}_{4}\end{array}$ & $\begin{array}{l}0.2 \\
0.1 \\
0.1\end{array}$ & $\begin{array}{l}0.175 \\
0.1\end{array}$ \\
\hline Di-cal & 2 & 1.75 \\
\hline Calcium carbonate & 0.75 & 0.75 \\
\hline Salt, iodized & 0.35 & 0.35 \\
\hline Antibiotic & 0.05 & 0.1 \\
\hline Total & 100 & 100 \\
\hline
\end{tabular}

Table 2. Phillip Lyvers swine rations, percent composition by weight, green group, 1996*

\begin{tabular}{|c|c|c|c|c|c|c|}
\hline $\begin{array}{l}\text { Feedstuff } \\
\text { Ingredients }\end{array}$ & $\begin{array}{l}\text { Diet No. } 1 \\
25-36 \mathrm{~kg} \text {; } \\
55-80 \mathrm{lb}\end{array}$ & $\begin{array}{c}\text { Diet No. } 2 \& 3 \\
36-64 \mathrm{~kg} \\
80-140 \mathrm{lb}\end{array}$ & $\begin{array}{c}\text { Diet No. } 4 \\
64-91 \mathrm{~kg} \text {; } \\
140-200 \mathrm{lb}\end{array}$ & $\begin{array}{c}\text { Diet No. } 5 \\
64-91 \mathrm{~kg} ; \\
140-200 \mathrm{lb}\end{array}$ & $\begin{array}{l}\text { Diet No. } 6 \\
91-104 \mathrm{~kg} \text {; } \\
200-230 \mathrm{lb}\end{array}$ & $\begin{array}{l}\text { Diet No. } 7 \\
91-104 \mathrm{~kg} \text {; } \\
200-230 \mathrm{lb}\end{array}$ \\
\hline Corn & 74.92 & 77.42 & 79.5 & 81.25 & 81.5 & 85 \\
\hline SBM (48\%) & 20.78 & 18.98 & 17.25 & 15.5 & 15.5 & 12 \\
\hline \multicolumn{7}{|l|}{ Suppl. or pre-mix: } \\
\hline Vitamin & 0.15 & 0.15 & 0.15 & 0.15 & 0.15 & 0.15 \\
\hline Lysine & 0.15 & 0.15 & 0.15 & 0.15 & 0.15 & 0.15 \\
\hline $\mathrm{CuSO}_{4}$ & 0.10 & 0.10 & & & & \\
\hline Di-cal & 2.75 & 2.1 & 1.75 & 1.75 & 1.5 & 1.5 \\
\hline Calcium carbonate & te 0.7 & 0.65 & 0.75 & 0.75 & 0.75 & 0.75 \\
\hline Salt, iodized & 0.35 & 0.35 & 0.35 & 0.35 & 0.35 & 0.35 \\
\hline Antibiotic & 0.1 & 0.1 & 0.1 & 0.1 & 0.1 & 0.1 \\
\hline Total & 100 & 100 & 100 & 100 & 100 & 100 \\
\hline
\end{tabular}

* Diets 1-3 for barrows and gilts, Diets $4 \& 6$ for gilts, Diets $5 \& 7$ for barrows.

$36.6 \mathrm{~m}(120 \mathrm{ft})$ long, each containing 12 pens and a total of 336 pigs. Pens are $3 \mathrm{~m}(10 \mathrm{ft})$ wide $\times 6.1 \mathrm{~m}(20 \mathrm{ft})$ long with partially slatted floors and a combination of wood and metal gate-type pen dividers. The ridge lines run EastWest. Height at the eaves is $2.4 \mathrm{~m}$ (8 ft), and manually adjustable curtains allow for openings up to approximately

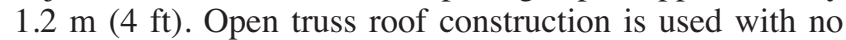
ceilings. Space allowance averages 28 pigs per pen, or approximately $0.66 \mathrm{~m}^{2} / \mathrm{pig}\left(7.1 \mathrm{ft}^{2} / \mathrm{pig}\right)$.

Weather data were obtained for each period from a weather station located at Bardstown, Kentucky, approximately $16 \mathrm{~km}$ (10 miles) from the farm. Data included maximum and minimum daily dry bulb temperatures and relative humidity $(\mathrm{RH})$. In addition, dry bulb temperatures and RH were monitored every half hour within each barn during 1996. Sensors were placed at a height of $1.8 \mathrm{~m}(5.9 \mathrm{ft})$ for dry bulb temperature between two barrow pens and two gilt pens (pens $3 \& 4,9.1 \mathrm{~m}$ $(30 \mathrm{ft})$ from the west end; and $9 \& 10,9.1 \mathrm{~m}(30 \mathrm{ft})$ from the east end; respectively), and in the center of the building. RH was measured at the same height in the center of the building.

\section{Simulation Parameters}

A moderately high lean growth genetic strain was used in the NCPIG model for lean growth potential, as calibrated against the first (white) group. Parameters for tissue growth curves were set to simulate performance of the Lyvers herd. Subsequent runs were not altered from the initial calibration curves. Diets fed were represented in the model using the components as indicated in tables 1-2. Initial pig weights for each sex in each group were established based upon the weight data collected on the farm. Weather data were used from the Bardstown weather data site for maximum and minimum daily temperatures and relative humidity for input to the model. The model then used those data to estimate internal temperatures and relative humidity each time step within the barns using the natural ventilation option in the model with misting (Bridges et al., 1992c). Air speed within the barn was set to a minimal level of $0.15 \mathrm{~m} / \mathrm{s}(30 \mathrm{ft} / \mathrm{min})$.

\section{RESULTS}

Tables 3 and 4 present results for the observed and simulated production statistics over the 1995 feeding

Table 3. Production performance, white group, 6/15/95 start date, grow-finish period*

\begin{tabular}{lcccc}
\hline & $\begin{array}{c}\text { Producer } \\
\text { Barrow }\end{array}$ & $\begin{array}{c}\text { Simulated } \\
\text { Barrow }\end{array}$ & $\begin{array}{c}\text { Producer } \\
\text { Gilt }\end{array}$ & $\begin{array}{c}\text { Simulated } \\
\text { Gilt }\end{array}$ \\
\hline Days on feed & 102.1 & 108 & 109.9 & 110 \\
Slaughter wt., kg (lb) & 107.0 & 107.6 & 107.2 & 107.5 \\
& $(235.9)$ & $(237.2)$ & $(236.3)$ & $(237.0)$ \\
ADF†, kg/day (lb/day) & 2.51 & 2.39 & 2.19 & 2.08 \\
& $(5.53)$ & $(5.27)$ & $(4.83)$ & $(4.59)$ \\
ADG $\neq$, kg/day (lb/day) & 0.82 & 0.78 & 0.77 & 0.77 \\
& $(1.81)$ & $(1.72)$ & $(1.70)$ & $(1.70)$ \\
F/G $\$$ & 3.13 & 3.06 & 2.9 & 2.71 \\
10th Rib BF, mm (in.) & 27.9 & 24.6 & 22.4 & 22.4 \\
& $(1.10)$ & $(0.97)$ & $(0.88)$ & $(0.88)$ \\
FFLIll, \% & 45.39 & 46.7 & 47.8 & 47.9 \\
\hline
\end{tabular}

* This data set used to calibrate growth curves for Lyvers barrows and gilts.

$\dagger$ ADF, Average Daily Feed.

* ADG, Average Daily Gain.

$\S \mathrm{F} / \mathrm{G}$, Feed to Gain ratio.

॥ FFLI, Fat Free Lean Index.

Table 4. Production performance, red group, 7/05/95 start date, grow-finish period

\begin{tabular}{lcccc}
\hline & $\begin{array}{c}\text { Producer } \\
\text { Barrow }\end{array}$ & $\begin{array}{c}\text { Simulated } \\
\text { Barrow }\end{array}$ & $\begin{array}{c}\text { Producer } \\
\text { Gilt }\end{array}$ & $\begin{array}{c}\text { Simulated } \\
\text { Gilt }\end{array}$ \\
\hline Days on Feed & 100.9 & 100 & 107.6 & 104 \\
Slaughter wt., kg (lb) & 107.0 & 107.5 & 107.2 & 107.5 \\
& $(235.9)$ & $(237.0)$ & $(236.3)$ & $(237.0)$ \\
ADF, kg/day (lb/day) & 2.45 & 2.54 & 2.13 & 2.21 \\
& $(5.40)$ & $(5.60)$ & $(4.70)$ & $(4.87)$ \\
ADG, kg/day (lb/day) & 0.82 & 0.83 & 0.78 & 0.81 \\
& $(1.81)$ & $(1.83)$ & $(1.72)$ & $(1.79)$ \\
F/G & 2.98 & 3.06 & 2.73 & 2.72 \\
10th Rib BF, mm (in.) & 25.4 & 25.1 & 21.6 & 22.6 \\
& $(1.0)$ & $(0.99)$ & $(0.85)$ & $(0.89)$ \\
FFLI, \% & 46.70 & 46.68 & 48.53 & 47.91 \\
\hline
\end{tabular}


Table 4. Production performance, red group, 7/05/95 start date, grow-finish period

\begin{tabular}{lcccc}
\hline & $\begin{array}{c}\text { Producer } \\
\text { Barrow }\end{array}$ & $\begin{array}{c}\text { Simulated } \\
\text { Barrow }\end{array}$ & $\begin{array}{c}\text { Producer } \\
\text { Gilt }\end{array}$ & $\begin{array}{c}\text { Simulated } \\
\text { Gilt }\end{array}$ \\
\hline Days on Feed & 100.9 & 100 & 107.6 & 104 \\
Slaughter wt., kg (lb) & 107.0 & 107.5 & 107.2 & 107.5 \\
& $(235.9)$ & $(237.0)$ & $(236.3)$ & $(237.0)$ \\
ADF, kg/day (lb/day) & 2.45 & 2.54 & 2.13 & 2.21 \\
& $(5.40)$ & $(5.60)$ & $(4.70)$ & $(4.87)$ \\
ADG, kg/day (lb/day) & 0.82 & 0.83 & 0.78 & 0.81 \\
& $(1.81)$ & $(1.83)$ & $(1.72)$ & $(1.79)$ \\
F/G & 2.98 & 3.06 & 2.73 & 2.72 \\
10th Rib BF, mm (in.) & 25.4 & 25.1 & 21.6 & 22.6 \\
& $(1.0)$ & $(0.99)$ & $(0.85)$ & $(0.89)$ \\
FFLI, \% & & & & \\
& 46.70 & 46.68 & 48.53 & 47.91 \\
\hline
\end{tabular}

Table 5. Production performance, simulated vs observed, green group, 6/05/96 start date, grow-finish period

\begin{tabular}{lcccc}
\hline & $\begin{array}{c}\text { Producer } \\
\text { Barrow }\end{array}$ & $\begin{array}{c}\text { Simulated } \\
\text { Barrow }\end{array}$ & $\begin{array}{c}\text { Producer } \\
\text { Gilt }\end{array}$ & $\begin{array}{c}\text { Simulated } \\
\text { Gilt }\end{array}$ \\
\hline Days on Feed & 94.7 & 93 & 99 & 96 \\
Slaughter wt., kg (lb) & 104.2 & 104.6 & 102.6 & 103.2 \\
& $(229.7)$ & $(230.6)$ & $(226.2)$ & $(227.5)$ \\
ADF, kg/day (lb/day) & 2.79 & 2.56 & 2.25 & 2.21 \\
& $(6.15)$ & $(5.64)$ & $(4.96)$ & $(4.87)$ \\
ADG, kg/day (lb/day) & 0.81 & 0.83 & 0.79 & 0.81 \\
& $(1.79)$ & $(1.83)$ & $(1.74)$ & $(1.79)$ \\
F/G & 3.44 & 3.08 & 2.87 & 2.71 \\
\hline
\end{tabular}

periods by group. Average feed intakes, daily gains and feed conversions were within $\pm 5 \%$ for both gilts and barrows, and back fat thicknesses were within $0.1 \%$ for gilts and $11 \%$ for barrows for the white (calibration) group, and $0.5 \%$ and $1.2 \%$ for the barrows and gilts of the red group, respectively.

Table 5 presents data for comparison of simulated and observed performance during 1996. Agreement between the observed and simulated data was within $\pm 10.4 \%$ for $\mathrm{ADG}, \mathrm{ADF}$, and $\mathrm{F} / \mathrm{G}$ ratios for barrows, and $\pm 5.6 \%$ for

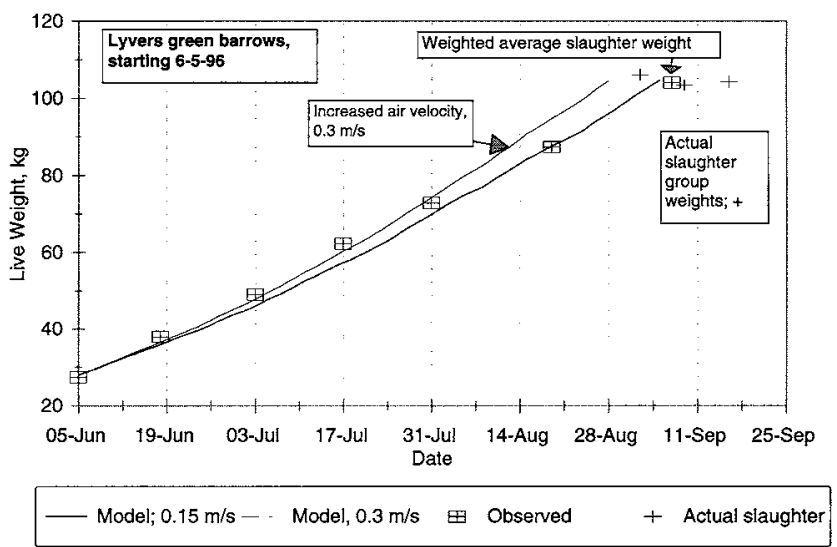

Figure 1-Live weight vs time for the simulated and observed green barrow group in 1996.

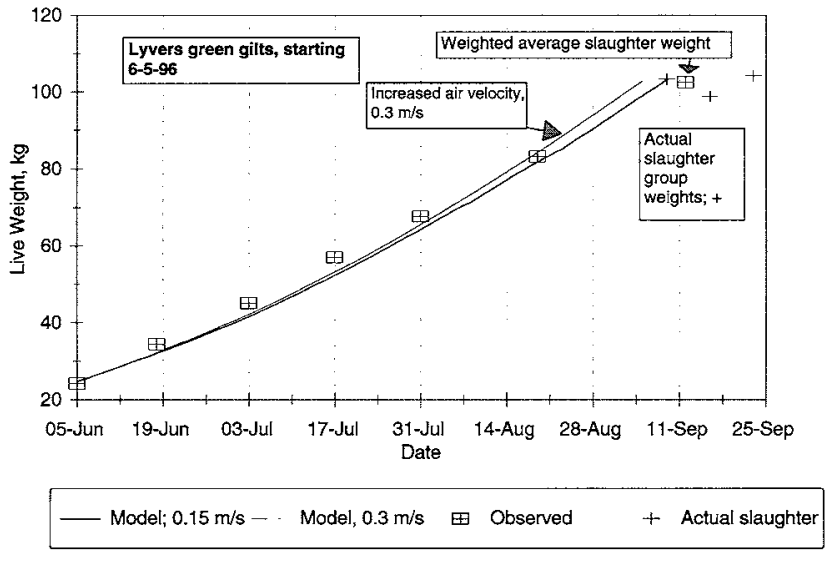

Figure 2-Live weight vs time for the simulated and observed green gilt group in 1996.

gilts. Tenth rib back fat and fat free lean index were not available by sex.

In addition to overall production performance, dynamic performance measures during the trials were also examined for the 1996 period. For the 1996 grow-finish period, intermediate animal weights were collected as described earlier. Figures 1 and 2 present comparisons between observed and simulated live weight for the green barrow and gilt groups, respectively. As indicated by the figures, the model was generally accurate, although animal weight was somewhat under-predicted during the 40 to $80 \mathrm{~kg}(90-180 \mathrm{lb})$ live weight range of the grow-finish period for the original assumption of $0.15 \mathrm{~m} / \mathrm{s}(30 \mathrm{ft} / \mathrm{min})$ air velocity in the pen. During the summer grow-finish period, the air velocity around the pigs is likely to be higher. We repeated the simulation runs with a higher air velocity of $0.30 \mathrm{~m} / \mathrm{s}(59 \mathrm{ft} / \mathrm{min})$. The graphs show that the model results more nearly represent the intermediate pig live weights using the revised air velocity level. However, with the higher air velocity, the pigs achieve slaughter weight earlier in the simulation runs than do the observed animals. The NCPIG model does not account for crowding effects on intake. The on-farm results presumably reflect a reduction in intake due to crowding during the latter stages of the finishing period. Since the NCPIG model does not currently represent this effect, the model pigs achieve slaughter weight earlier. Future plans include adding logic to the NCPIG model to account for the effect of crowding on intake.

\section{SUMmARY AND CONCLUSIONS}

The NCPIG model was tested against observed commercial on-farm data for 1995 and 1996 summer time conditions in naturally ventilated grow-finish swine facilities. Detailed production information comparisons were made between the NCPIG model and producer data. Production data from the model were found to be generally within $\pm 5 \%$ of the observed data for most production measures, and the accuracy of the model for the calibration group was not diminished for subsequent groups. Intermediate live weight data collected from the model generally agreed with observed data for the 1996 growfinish period, with slightly higher weights for the observed 
animals as compared to the model data in the 40 to $80 \mathrm{~kg}$ (90-180 lb) weight range portion of the overall 25 to $105 \mathrm{~kg}(55-230 \mathrm{lb})$ grow finish period. Adjustment of air velocity reduced the discrepancy between intermediate observed and simulated weights, although a discrepancy exists between simulated and observed slaughter time, presumably due to crowding effects. An improvement in NCPIG would be the planned addition of logic to consider crowding effects on intake. The results of these comparisons demonstrate the validity of the NCPIG model for simulation of grow-finish swine performance of moderately high-lean-growth pigs during summer time conditions in the Southeast.

AcKnowledgments. The authors wish to acknowledge the contributions of several members of NC-204 and others to development and testing of the NCPIG model, including James L. Usry, Heartland Lysine, Inc., Timothy S. Stahly, Iowa State University, John A. Nienaber, USDA-MARC, and Otto J. Loewer, University of Arkansas. Also, we wish to acknowledge the assistance and cooperation of $\mathrm{Mr}$. Phillip Lyvers, Loretto, Kentucky, in our commercial farm comparisons with NCPIG, and of Mr. Brandon Riley, undergraduate student assistant, in data collection.

\section{REFERENCES}

Black, J. L., R. G. Campbell, I. H. Williams, K. J. James, and G. T. Davis. 1986. Simulation of energy and amino acid utilization in the pig. Res. \& Develop. in Agric. 3(3): 121-145.

Bridges, T. C., L. W. Turner, T. S. Stahly, J. L. Usry, and O. J. Loewer. 1992a. Modeling the physiological growth of swine, Part 1: Model logic and growth concepts. Transactions of the ASAE 35(3): 1019-1028.

Bridges, T. C., L. W. Turner, J. L. Usry, and J. A. Nienaber. 1992b. Modeling the physiological growth of swine, Part 2: Validation of model logic and growth concepts. Transactions of the ASAE 35(3): 1029-1033.

Bridges, T. C., R. S. Gates, and L. W. Turner. 1992c. Stochastic assessment of evaporative misting for growing-finishing swine in Kentucky. Applied Engineering in Agriculture 8(5): 685-693.
Bruce, J. M., and J. J. Clark. 1979. Models of heat production and critical temperature for growing pigs. Animal Prod. 28(3): 353369.

DeShazer, J. A., M. J. Milanuk, D. L. Watt, H. Xin, R. Vansteelant, and R. C. Ewan. 1988. NCCISWINE: The environmental and housing component. ASAE SP 01-88. In Proc. 3rd Int'l Livestock Environment Symp., 203-210, Toronto, Canada. St. Joseph, Mich.: ASAE.

Ewan, R. C., and J. A. DeShazer. 1988. Mathematical modeling of the growth of swine. ASAE SP 01-88. In Proc. 3rd Int'l Livestock Environment Symp., 211-217, Toronto, Canada. St. Joseph, Mich.: ASAE.

Fialho, F. B., R. A. Bucklin, and F. S. Zazueta. 1997a. Simulation model of swine growth and development. In Livestock Environment V, 1047-1054, Minneapolis, Minn. St. Joseph, Mich.: ASAE.

Fialho, F. B., R. A. Bucklin, F. S. Zazueta, and R. Myer. 1997b. Simulation model of heat balance in swine. In Livestock Environment V, 1040-1046, Minneapolis, Minn. St. Joseph, Mich.: ASAE.

Moughan, P. J., W. C. Smith, and G. Pearson. 1987. Description and validation of a model simulating growth in the pig (20-90 $\mathrm{kg}$ live weight). New Zealand J. Agric. Res. 30(4): 480-487.

Pomar, C., D. L. Harris, and F. Minvielle. 1991. Computer simulation model of swine production systems: 1. Modeling the growth of young pigs. J. Animal Sci.69(4): 1468-1488.

Teter, N. C., J. A. DeShazer, and T. L. Thompson. 1973. Operational characteristics of meat animals, Part 1: Swine. Transactions of the ASAE 16(1): 157-159.

Usry, J. L., L. W. Turner, T. C. Bridges, and J. A. Nienaber. 1992. Modeling the physiological growth of swine, Part 3: Heat production and interaction with the environment. Transactions of the ASAE 35(3): 1035-1042.

Watt, D. L., J. A. DeShazer, R. C. Ewan, R. L. Harrold, D. C. Mahan, and G. D. Schwab. 1987. NCCISWINE: Housing, nutrition and growth simulation model. Appl.Agric. Res. 2(4): 218-223.

Whittemore, C. T., and R. H. Fawcett. 1976. Theoretical aspects of a flexible model to simulate protein and lipid growth in pigs. Animal Prod. 22(1): 87-96. 